\title{
Adsorptive modelling of toxic cations and ionic dyes onto cellulosic extract
}

\author{
Jonathan O. Babalola ${ }^{1}$ Temitope M. Bamidele ${ }^{2}$ Elisha A. Adeniji ${ }^{1}$. \\ Nnenna W. Odozi ${ }^{1} \cdot$ Abimbola M. Olatunde $^{1} \cdot$ Martins O. Omorogie ${ }^{3,4}$
}

Received: 19 October 2016/Accepted: 22 October 2016/Published online: 2 November 2016

(c) Springer International Publishing Switzerland 2016

\begin{abstract}
This work reports the abstractive potential of Parkia Biglobosa seed waste (PSW) and Parkia Biglobosa cellulosic extract (PBCE) for the removal of $\mathrm{Cr}(\mathrm{VI}), \mathrm{Pb}(\mathrm{II})$, methylene blue (MB) and congo red (CR) from aqua system. Physicochemical analyses carried out for these biomaterials were proximate analysis, Fourier transform infra red (FTIR) Spectrophotometry and scanning electron microscopy (SEM). The FTIR data showed that $-\mathrm{O}-\mathrm{H},-\mathrm{C}=\mathrm{C}-,-\mathrm{C}=\mathrm{O}$, $-\mathrm{C} \equiv \mathrm{C}-$ and $-\mathrm{S}-\mathrm{H}$ functional groups were responsible for the sequestration of $\mathrm{Cr}(\mathrm{VI}), \mathrm{Pb}(\mathrm{II}), \mathrm{MB}$ and $\mathrm{CR}$ from aqua system. The equilibrium data fitted best to Langmuir isotherm model with the highest adsorption obtained for MB, being $1498.42 \mathrm{mg} / \mathrm{g}$ at $298 \mathrm{~K}$ and $403.23 \mathrm{mg} / \mathrm{g}$ at $298 \mathrm{~K}$ for PSW and PBCE respectively. Pseudo-second order model gave the best fits for the kinetic data among two other kinetic models used. The PSW and PBCE biomaterials demonstrated good potentials for the removal of toxic $\mathrm{Cr}(\mathrm{VI})$, $\mathrm{Pb}(\mathrm{II}), \mathrm{MB}$ and $\mathrm{CR}$ from aqua systems.
\end{abstract}

Jonathan O. Babalola

bamijibabalola@yahoo.co.uk

$\triangle$ Martins O. Omorogie

osaigbovooohireimen@gmail.com; omorogiem@run.edu.ng; martinso@vut.ac.za

1 Department of Chemistry, University of Ibadan, Ibadan, Nigeria

2 Department of Chemistry, Oklahoma State University, Stillwater, OK, USA

3 Environmental and Chemical Processes Research Group, Department of Chemical Sciences, Redeemer's University, P.M.B. 230, Ede, Osun State, Nigeria

4 Adsorption and Catalysis Research Laboratory, Department of Chemistry, Vaal University of Technology, Private Bag X021, Andries Potgieter Boulevard, Vanderbijlpark 1900, South Africa
Keywords Parkia seed waste $\cdot$ Parkia Biglobosa cellulosic extract · Intraparticle diffusion - Equilibrium . Thermodynamics

\section{Introduction}

The quest for good quality living for flora, fauna and human beings has drawn researchers' enthusiasm in recent times to toxic cations and ionic dyes generated from global industrial activities. Various water sources contaminated by these pollutants have become a serious environmental challenge. Heavy metals and dyestuffs pose serious threat to man, terrestrial and aquatic habitats, and to a very great extent hamper ecological sustainability (Omorogie et al. 2012).

Chromium is one of the most dangerous toxic metals, widely found in industrial wastewater comprising metal finishing, electroplating, tanning, textile, leather, mining, fertiliser and photography industries (Barnhart 1997) and effluents produced from the aerospace (Owlad et al. 2010). $\mathrm{Cr}(\mathrm{VI})$ exists as extremely soluble, highly toxic and recalcitrant chromate oxoanions $\left(\mathrm{HCrO}^{4-}\right.$ or $\left.\mathrm{Cr}_{2} \mathrm{O}_{7}{ }^{2-}\right)$ that can transfer freely in aqueous environments (Mitra et al. 2011). Persistent exposure to $\mathrm{Cr}(\mathrm{VI})$ causes cancer in the digestive tract and lungs, skin dermatitis, bronchitis, perforation of the nasal septum, severe diarrhoea and haemorrhage (Deng and Alan 1996, Marjanovic et al. 2011). In natural waters, the range of $\mathrm{Cr}(\mathrm{VI})$ concentration is as high as 5.2-208,000 mg/L (Richard and Bourg 1991).

Lead is a known environmental pollutant that can be found in industrial wastewaters such as acid battery, ceramic and glass manufacturing, metal planting and finishing, printing, tanning, and production of lead additives for gasoline. Efforts in reducing lead concentration in 
industrial wastewaters are driven by the hazards it poses on the ecosystem. Current US Environmental Protection Agency (US EPA) drinking water standard for lead is $0.015 \mathrm{mg} / \mathrm{L}$ ( $\mathrm{Li}$ and Wang 2009). Acute lead poisoning in humans causes severe damage to the kidneys, liver, brain, and nervous system while a long term exposure may induce sterility, abortion and neonatal death (Gercel and Gercel 2007; Sulaymon et al. 2009).

Synthetic dyes have been increasingly utilised in textile industries, dye manufacturing industries, paper and pulp mills, tanneries, electroplating factories, food companies, etc. It is reported that approximately 100 tonnes of dyes are discharged into waste streams by the textile industry/year (Wong et al. 2003). Dyes are considered recalcitrant pollutant on aquatic environment because they give undesirable colours to water (Al-Degs et al. 2004) and reduce light penetration and photosynthesis (Wang et al. 2005; Ponnusami et al. 2007; Mane et al. 2007). Most dyes are considered to be non-oxidisable substances by traditional biological and physical treatment (Weber and Morris 1962). The disposal of coloured wastes such as dyes into flowing waters consequent in damaging the environment as they constitutes toxins to aquatic life. The difficulties experienced in removing toxic metals and dyes from industrial wastewaters have led to the use of different adsorbents by researchers (Mahir et al. 2004).

The panacea to rescue polluted environment from these harmful substances led the utilisation of some conventional techniques such as ion exchange, chemical co-precipitation, electrochemical precipitation, reverse osmosis, solvent extraction, solid phase extraction, evaporation, membrane filtration and adsorption (for toxic metals) (Say et al. 2008) and sonochemical degradation (Minero et al. 2005), chemical oxidation, flocculation, photocatalytic decomposition (Wu and Chern 2006) and electro-catalytic degradation (for dyes) (Ma et al. 2009).

Over the years, researchers have used various biosorbents and materials in sequestering toxic metals and dyes from aqueous solutions. These include Nauclea diderrichii seed biomass waste (Omorogie et al. 2012), Zea mays cob, sugarcane bagasse (Sharma and Forster 1994), Japanese cedars (Aoyama et al. 2005), Thuja orientalis (Oguz 2005), reed (Rawajfih and Nsour 2008), rice bran (Singh et al. 2005), wheat bran (Dupont and Guillon 2003), soya cake (Daneshvar et al. 2002), coconut husk (Tan et al. 1993), rice husk (Krishnani et al. 2008), walnut hull (Wang et al. 2009), Fomes fomentarius, Phellinus igniarius (Maurya et al. 2006), Hydrilla verticillata (Low et al. 1993), algae Gelidium (Vilar et al. 2007), Ulva lactuca (El Sikaily et al. 2006), Posidonia oceania, Enteromorpha spp. (Ncibi et al. 2009), Aspergillus niger (Fu and Viraraghavan 2000), Caulerpa lentillifera (Marungrueng and Pavasant 2007), waste red mud (Namasivayam and Arasi 1997), waste orange peel
(Namasivayam et al. 1996), cellulose/magnetite/activated carbon (Zhu et al. 2011), Barbula lambarenensis (OluOwolabi et al. 2012), Zea mays seed chaff (Babalola et al. 2016a), mesoporous $\mathrm{SiO}_{2}$ /graphene oxide, $\mathrm{TiO}_{2}$ and $\mathrm{MnO}_{2}$ nanoparticles-modified Nauclea diderrichii biomass waste (Omorogie et al. 2014a, b, 2015, 2016a), Cedrela odorata (Babalola et al. 2016b), among others.

Parkia biglobosa paste is a local food seasoning agent known as 'dawadawa' in Ghana, 'iru' in Nigeria and Benin Republic, and 'soumbala' in Burkina Faso. It is obtained from fermented dried seeds of the African locust bean (Parkia biglobosa). This plant is a perennial leguminous tree which belongs to the family and sub family $M i$ mosoideae and Leguminosae respectively. It grows in the savannah region of West Africa (Campbell-Platt 1980). The tree is not normally cultivated, but can be seen in population of two or more in the savannah region of West Africa (Gupta et al. 1992). The Parkia tree plays a vital ecological role in cycling of nutrients from deep soils, by holding the soil particles to prevent soil erosion with the aid of its roots. It also provides shade where it is found (Campbell-Platt 1980; Gupta et al. 1992; Irvine 1961; Hagos 1962).

As local food seasoning agent, it serves as a nutritive non-meat protein and flavouring agent for local soups (Poopal and Laxman 2009) in Nigeria, Northern Ghana and some other West African countries. Parkia biglobosa paste has a good nutritional and medicinal value that reduces high blood pressure. Parkia biglobosa has a wide distribution ranging across nineteen African countries including Nigeria, Sudan, Senegal, Gambia, Guinea Bissau, Guinea, Sierra Leone, Mali, Côte d'Ivoire, Burkina Faso, Ghana, Togo, Benin, Niger, Cameroon, Chad, Central African Republic, Zaire, Sudan and Uganda (Hall et al. 1991). Parkia biglobosa tree also plays a vital economic role in recycling nutrients from the soil. Parkia biglobosa seed that is grown into the tree plant has an outer covering that is thrown away, hence, constituting environmental pollution problem. This Parkia biglobosa seed waste (PSW) was collected from one of its growing sites in Ibadan $\left(7^{\circ} 23^{\prime} 16^{\prime \prime} \mathrm{N}, 3^{\circ} 53^{\prime} 47^{\prime \prime} \mathrm{E}\right)$, Nigeria, West Africa. The cellulose extracted from Parkia biglobosa was used for this research.

Table 1 Proximate analysis of PSW and PBCE

\begin{tabular}{lrr}
\hline Parameters & PSW & PBCE \\
\hline \%Moisture content & 4.74 & 3.34 \\
\%Crude protein & 7.66 & 7.99 \\
\%Crude fat & 10.71 & 9.19 \\
\%Crude fibre & 26.77 & 28.98 \\
\%Ash & 11.67 & 11.82 \\
\%Carbohydrate & 38.45 & 38.68 \\
\hline
\end{tabular}


Table 2 Assignment of FTIR spectra bands for PSW and PBCE

\begin{tabular}{lllll}
\hline PBCE & & & PSW \\
\cline { 1 - 2 } $\begin{array}{llll}\text { Wavenumbers } \\
\left(\mathrm{cm}^{-1}\right)\end{array}$ & Functional groups & $\begin{array}{l}\text { Wavenumbers } \\
\left(\mathrm{cm}^{-1}\right)\end{array}$ & Functional groups \\
\hline 3774 & Free $-\mathrm{OH}$ & Not present & - \\
3434 & $-\mathrm{N}-\mathrm{H}$ stretch & 3445 & $-\mathrm{N}-\mathrm{H}$ stretch \\
Not present & - & 2923 & $-\mathrm{C}-\mathrm{H}$ stretch of $\mathrm{CH}_{3}, \mathrm{CH}_{2}$ \\
2357 & $-\mathrm{S}-\mathrm{H}$ stretch of sulphydryl & 2368 & $-\mathrm{S}-\mathrm{H}$ stretch of sulphydryl \\
1632 & $-\mathrm{C}=\mathrm{O}$ stretch & 1632 & $-\mathrm{C}=\mathrm{O}$ stretch \\
1366 & $-\mathrm{C}-\mathrm{H}$ bend of $\mathrm{CH}_{2}$ and $\mathrm{CH}_{3}$ of hemicelluloses, $-\mathrm{C}-\mathrm{O}$ & 1385 & $-\mathrm{C}-\mathrm{H}$ bend of $\mathrm{CH}_{2}$ and $\mathrm{CH}_{3}$ of hemicelluloses, $-\mathrm{C}-\mathrm{O}$ \\
1034.33 & stretch of ketones and lactones & & stretch of ketones and lactones \\
666.72 & $-\mathrm{C}-\mathrm{O}$ bend & $-\mathrm{C}-\mathrm{H}$ aromatic (out of plane bend) & Not present & -
\end{tabular}

Various biological materials comprise lignin and cellulose as their major components and possess polar functional groups such as alcohols, aldehydes, ketones, carboxylic acids, phenolics, sulphydryls aminos, amines, thiols and ethers. That have the ability to bind to heavy metals by donation of a lone pair of electrons to form complexes with the metal ions in solution (Pagnanelli et al. 2003). Celluloses have been known to be good adsorbents for the removal of toxic cations and ionic dyes (Pagnanelli et al. 2003). Therefore, this work evaluates the abstractive potential of PSW and PBCE for toxic cations and ionic dyes.

\section{Experimental}

\section{Preparation of PSW and PBCE}

Parkia biglobosa seeds were obtained from the Takie market in Ogo-Oluwa Local Government Area of Ogbomoso $\left(8^{\circ} 08^{\prime} \mathrm{N}, 4^{\circ} 15^{\prime} \mathrm{E}\right)$, Southwest Nigeria. They were stored in a cool dry place till the time of usage. The leaves and fruits of the plant specimen were taken to the Herbarium section of the Department of Botany, University of Ibadan $\left(7^{\circ} 23^{\prime} 16^{\prime \prime} \mathrm{N}, 3^{\circ} 53^{\prime} 47^{\prime \prime} \mathrm{E}\right)$, Nigeria for botanical identification. Fifty grammes of the peel waste was removed from the outer coverings of the seeds. It was dried under the sun for few days and pulverised.

Cellulose powder was extracted from the dried peel waste of Parka biglobosa by a process of extraction using toluene-ethanol $(2: 1 \mathrm{v} / \mathrm{v})$ for $6 \mathrm{~h}$ to remove the waxy components. Thereafter, this peel waste was hydrolysed using $0.5 \%$ sulphuric acid at $100{ }^{\circ} \mathrm{C}$ for $2 \mathrm{~h}$. The hydrolysed peel waste was washed with water and filtered. The resulting pulp was treated with solutions containing $\mathrm{NaOH}$ and $\mathrm{Na}_{2} \mathrm{~S}(21: 7 \mathrm{w} / \mathrm{w})$ at a temperature of about $100{ }^{\circ} \mathrm{C}$ in $1 \mathrm{~L}$ and then washed with de-ionized water by filtration until it became colourless. The white cellulose extract obtained was washed with de-ionized water and filtered, until the $\mathrm{pH}$ of the filtrate was 7.0. The cellulose extract obtained from PSW was then air dried and ground to powder (particle size between 300 and $450 \mu \mathrm{m}$ ). It was then stored in a sealed glass container and kept for experimental use. The cellulose obtained was dried in an
Fig. 1 The SEM images of a PSW, b PBCE
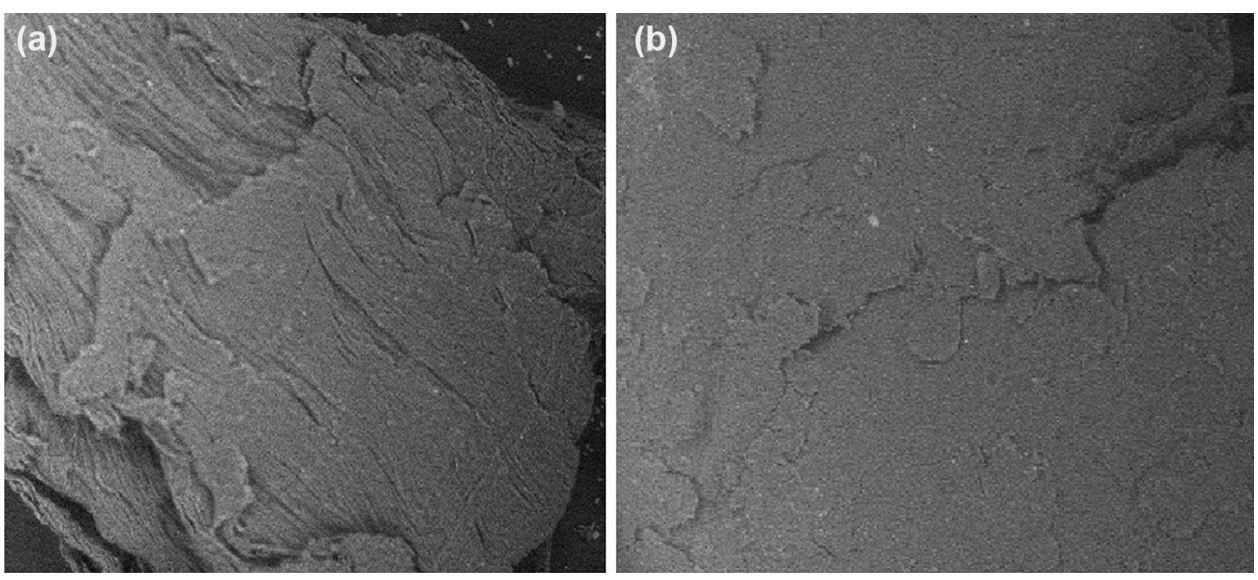

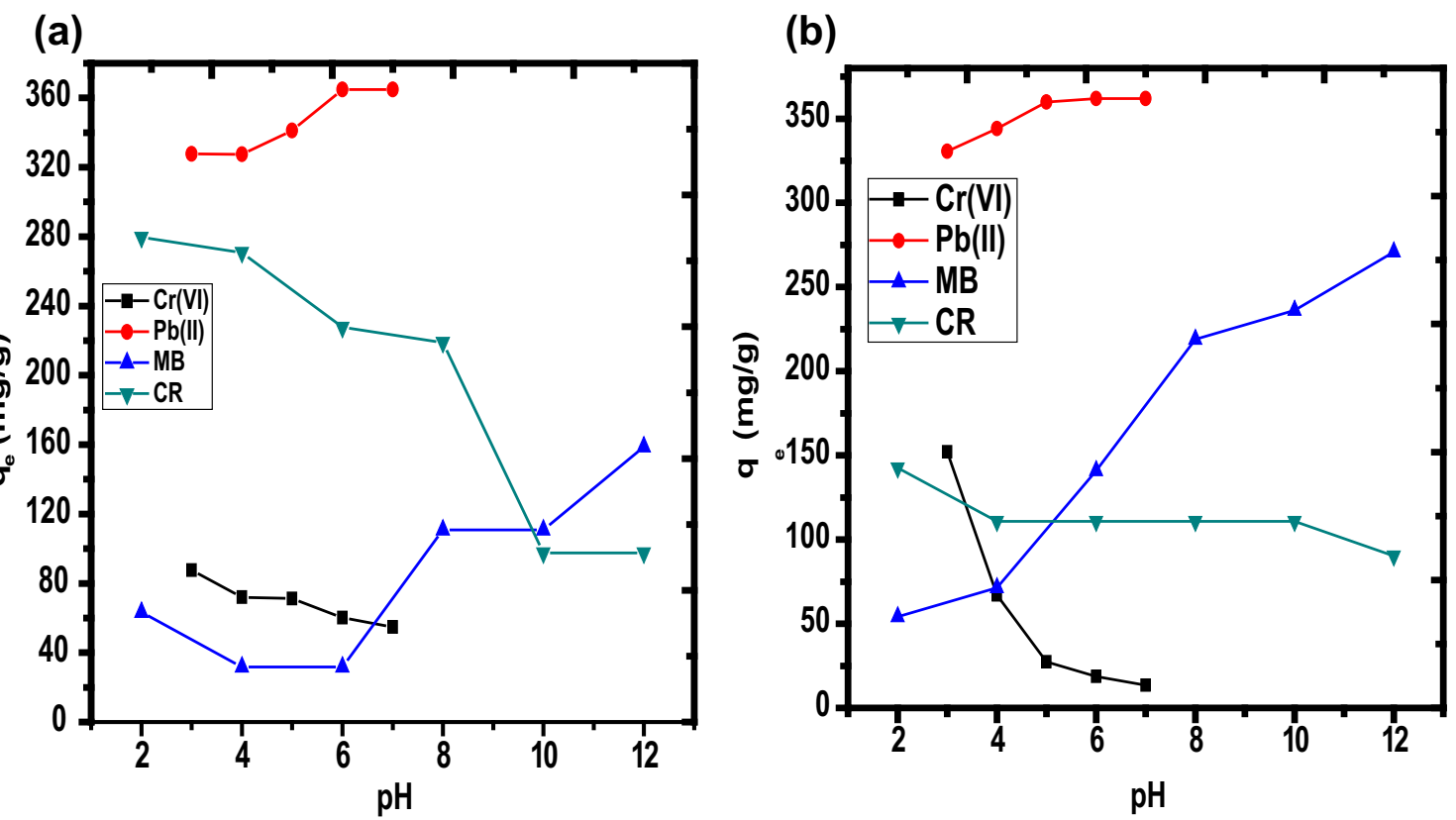

Fig. 2 The plots of the amount of $\mathrm{Cr}(\mathrm{VI}), \mathrm{Pb}(\mathrm{II}), \mathrm{MB}$ and $\mathrm{CR}$ adsorbed, $q_{e}(\mathrm{mg} / \mathrm{g})$ by a PSW against $\mathrm{pH}, \mathbf{b} \mathrm{PBCE}$ against $\mathrm{pH}$

oven and weighed. The percentage yield of the PBCE was calculated using:

$\%$ Yield $=\frac{\text { Mass of dried cellulose obtained }}{50 \mathrm{~g}} \times 100$

\section{Chemical reagents}

All chemical reagents were of analytical grade. Deionized water, $\mathrm{Pb}\left(\mathrm{NO}_{3}\right)_{2}, \mathrm{CrO}_{3}$, methylene blue (MB) and congo red (CR). Accurately weighed amounts of toxic metals and ionic dyes were used in preparing aqueous solutions of $1000 \mathrm{mg} / \mathrm{L} \mathrm{Cr}^{6+}, \mathrm{Pb}^{2+}, \mathrm{MB}$ and $\mathrm{CR}$. These solutions were diluted to different working concentrations when needed.

\section{Physicochemical characterisations of PSW and PBCE}

Fourier transform infra red (FTIR) was used in determining the functional groups present in loaded and unloaded biomass of PSW and PBCE. FTIR spectra of unloaded biomass and metal loaded biomass were recorded at $400-4000 \mathrm{~cm}^{-1}$ using FTIR Spectrophotometer JASCO430 Model.

Proximate analysis was carried out on PSW and PBCE according to the published protocol of the Association of Official Analytical Chemist, (AOAC 1990). This constitutes the classes of food present in samples such as carbohydrate, crude fibre, crude protein, crude fat, ash content and moisture content. The particle size of the PSW and
PBCE used was between 300 and $450 \mu \mathrm{m}$. The PSW and PBCE were further characterised by scanning electron microscopy (SEM) using the JEOL JSM-6390 LV Model, available at the Nigerian Liquified Natural Gas (NLNG) Multi-user Laboratories, Faculty of Engineering, Ahmadu Bello University, Zaria, Nigeria.

\section{Optimization of experimental variables}

\section{Initial solution $\mathrm{pH}$ Study}

For initial solution $\mathrm{pH}$ study, $10 \mathrm{mg}$ of PSW and PBCE was contacted with $25 \mathrm{~mL}$ of $150 \mathrm{mg} \mathrm{L}^{-1} \mathrm{Cr}^{6+}, \mathrm{Pb}^{2+}, \mathrm{MB}$ and CR solutions in $60 \mathrm{~mL}$ plastic bottles (high-density polyethylene) at agitation speed of $200 \mathrm{rpm}$ using thermostatic water bath (Haake Wia Model) at temperature of $298 \mathrm{~K}$. The $\mathrm{pHs}$ of the toxic metals and dye solutions were adjusted by $\mathrm{pH}$ meter Jenway 3520 Model from 3.0-7.0 and $2.0-12.0$ using $0.1 \mathrm{M} \mathrm{HCl}$ or $\mathrm{NaOH}$ respectively. The clear supernatants of toxic metals and dyes were obtained by centrifugation using Hitachi high-speed refridgerated centrifuge. The residual concentrations of $\mathrm{Cr}^{6+}$ and $\mathrm{Pb}^{2+}$ in the aqueous solutions were analysed using atomic absorption spectrophotometer (AAS) Buck 205 Model. The residual concentrations of $\mathrm{MB}$ and $\mathrm{CR}$ were analysed by UV/Vis Spectrophotometer Jenway 6505 Model at maximum wavelength of absorption, $\lambda_{\max }=606 \mathrm{~nm}$ for $\mathrm{MB}$ and $\lambda_{\max }=518 \mathrm{~nm}$ for $\mathrm{CR}$ respectively. The optimum $\mathrm{pH}$ values obtained from $\mathrm{pH}$ study were used for further studies. 

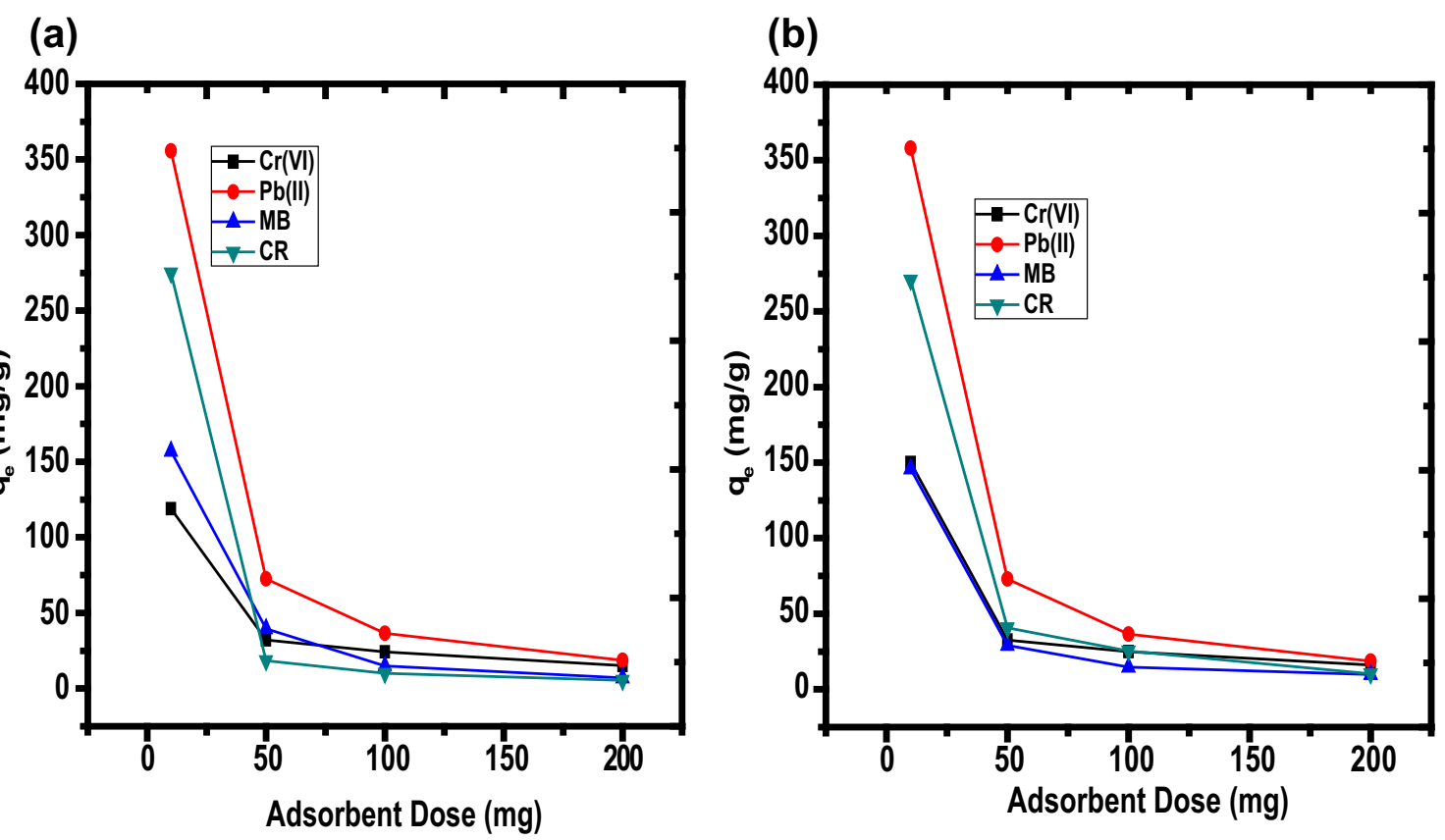

Fig. 3 The plots of the amount of $\mathrm{Cr}(\mathrm{VI}), \mathrm{Pb}(\mathrm{II}), \mathrm{MB}$ and $\mathrm{CR}$ adsorbed, $q_{e}(\mathrm{mg} / \mathrm{g}$ ) by a PSW against biomass dose (mg), b PBCE against adsorbent dose (mg)

(a)

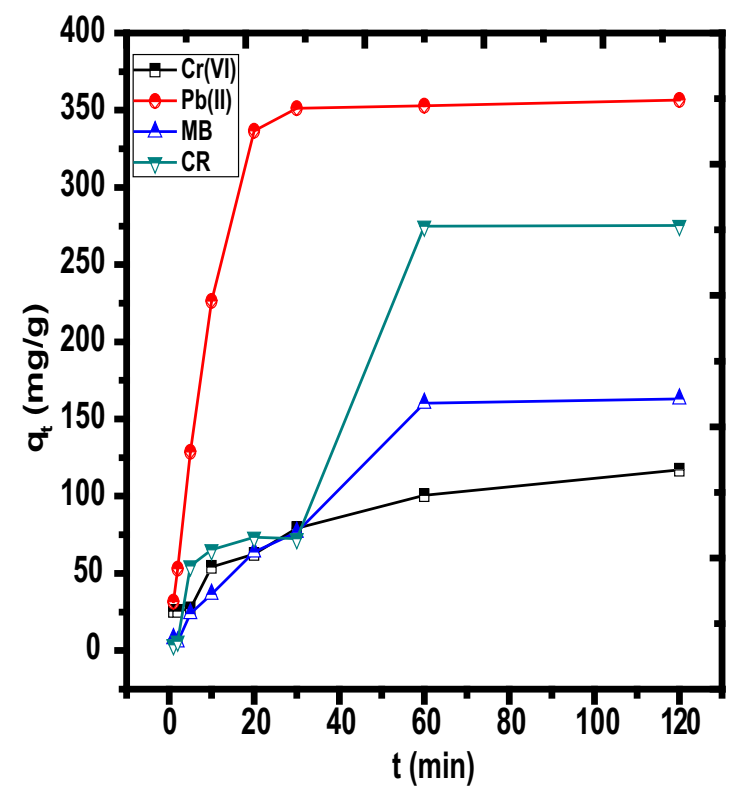

(b)

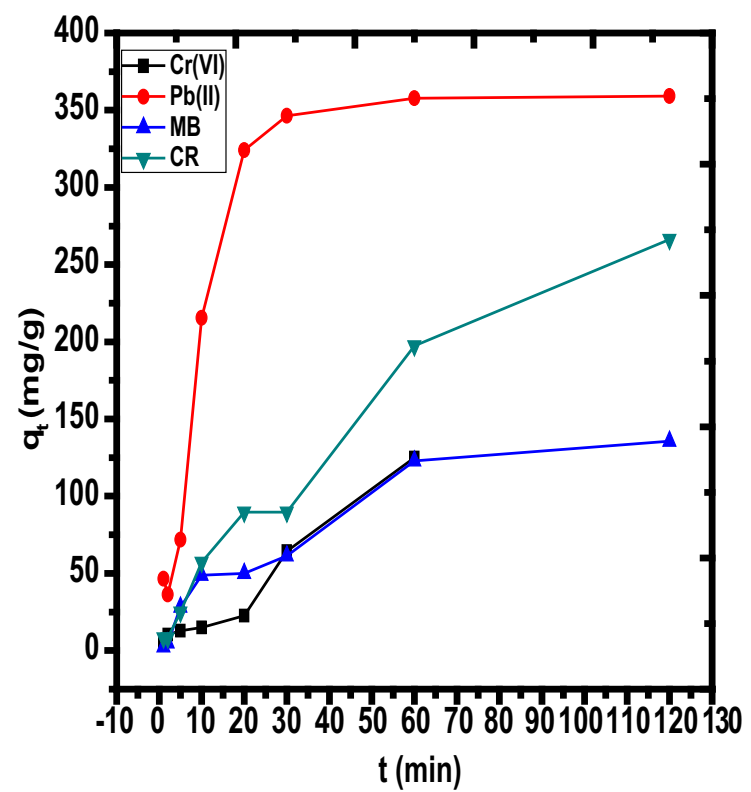

Fig. 4 The plots of the amount of $\mathrm{Cr}(\mathrm{VI}), \mathrm{Pb}(\mathrm{II}), \mathrm{MB}$ and $\mathrm{CR}$ adsorbed, $q_{t}(\mathrm{mg} / \mathrm{g})$ by a PSW against time $t(\mathrm{~min}), \mathbf{b} \mathrm{PBCE}$ against time $t(\mathrm{~min})$

\section{Equilibrium, kinetic and thermodynamics studies}

Equilibrium, thermodynamic and temperature studies were carried out in batch mode, with initial concentrations of $150-1000 \mathrm{mg} / \mathrm{L}$ of $25 \mathrm{Ml} \mathrm{Cr}^{6+}, \mathrm{Pb}^{2+}, \mathrm{MB}$ and $\mathrm{CR}$ solutions in $60 \mathrm{~mL}$ high-density polyethylene bottles contacted with $10 \mathrm{mg}$ of PSW and PBCE at optimum pHs obtained from $\mathrm{pH}$ study at 298-328 $\mathrm{K}$ respectively, agitation speed of $200 \mathrm{rpm}$ using thermostatic water bath (Haake Wia Model).

Kinetic and contact time studies were also carried out by contacting $10 \mathrm{mg}$ of PSW and PBCE with $25 \mathrm{~mL} \mathrm{Cr}^{6+}$, $\mathrm{Pb}^{2+}, \mathrm{MB}$ and $\mathrm{CR}$ solutions of initial concentration of $150 \mathrm{mg} / \mathrm{L}$ in $60 \mathrm{~mL}$ high-density polyethylene bottles at 
various time intervals of $1-120 \mathrm{~min}$ respectively, at optimum pHs, agitation speed of $200 \mathrm{rpm}$ using thermostatic water bath (Haake Wia Model) at $298 \mathrm{~K}$. The amounts of $\mathrm{Cr}^{6+}, \mathrm{Pb}^{2+}, \mathrm{MB}$ and $\mathrm{CR}$ adsorbed by PSW and PBCE were calculated using:

$q_{e}=\frac{\left(C_{\mathrm{i}}-C_{e}\right) V}{W}$

where $C_{\mathrm{i}}$ is the initial concentration of metal ion $(\mathrm{mg} / \mathrm{L})$, $C_{e}$ is the equilibrium concentration of residual metal ion in the solution $(\mathrm{mg} / \mathrm{L}), V$ is the volume of the aqueous solution containing metal ions $(L), W$ is the weight of adsorbent (g) and $q_{e}$ is the amount of metal ion adsorbed by the adsorbent $(\mathrm{mg} / \mathrm{g})$.

Effects of biomass dose were carried out by contacting $10-200 \mathrm{mg}$ of PSW and PBCE with $25 \mathrm{~mL}$ of $150 \mathrm{mg} \mathrm{L}^{-1} \mathrm{Cr}^{6+}, \mathrm{Pb}^{2+}, \mathrm{MB}$ and $\mathrm{CR}$ solutions in $60 \mathrm{~mL}$ high-density polyethylene bottles at optimum $\mathrm{pHs}$, agitation speed of $200 \mathrm{rpm}$ using thermostatic water bath (Haake Wia Model) at $298 \mathrm{~K}$.
Experimental data obtained from equilibrium, kinetic and thermodynamic studies were modelled using Freundlich model (Freundlich 1906), Langmuir model (Langmuir 1916), Dubinin-Radushkevich model (Dubinin 1960), pseudo-second order (Ho and McKay 1999), pseudo-first order (Lagergren 1898), Weber-Morris intraparticle diffusion (Weber and Morris 1963) models and Van't Hoff equation (Ho et al. 2000) respectively, whose linear forms are mathematically written as;

$\ln q_{e}=\ln k_{f}+1 / n \ln C_{e}$

$\frac{C_{e}}{q_{e}}=\frac{1}{K_{L} q_{\max _{L}}}+\frac{C_{e}}{q_{\max _{L}}}$

$\ln q_{e}=\ln q_{m}-\beta \varepsilon^{2}$

where $E=2 \beta^{-1 / 2}$ and $\varepsilon^{2}=\left\{R T \ln \left(1+1 / C_{e}\right)\right\}^{2}$

$\frac{t}{q_{t}}=\frac{t}{q_{e}}+\frac{1}{k_{2} q_{e}^{2}}$

$\ln \left(q_{e}-q_{t}\right)=\ln q_{e}-k_{1} t$

Table 3 The adsorption capacities, $q_{\max _{L}}(\mathrm{mg} / \mathrm{g})$ of some adsorbents used by researchers

\begin{tabular}{|c|c|c|c|c|c|}
\hline \multirow[t]{2}{*}{ Adsorbents } & \multirow[t]{2}{*}{ References } & \multicolumn{4}{|c|}{$q_{\max _{L}}(\mathrm{mg} / \mathrm{g})$} \\
\hline & & $\mathrm{Cr}(\mathrm{VI})$ & $\mathrm{Pb}(\mathrm{II})$ & MB & $\mathrm{CR}$ \\
\hline Sugarcane bagasse & (Sharma and Forster 1994) & 23.00 & & & \\
\hline Japanese Cedars & (Aoyama et al. 2005) & 71.94 & & & \\
\hline Thuja orientalis & (Oguz 2005) & 48.80 & & & \\
\hline Reed & (Rawajfih and Nsour 2008) & 33.00 & & & \\
\hline Rice bran & (Singh et al. 2005) & 285.71 & & & \\
\hline Wheat bran & (Dupont and Guillon 2003) & 35.00 & & & \\
\hline Phellinus igniarius & (Maurya et al. 2006) & & & 204.38 & \\
\hline Fomes fomentarius & (Maurya et al. 2006) & & & 232.73 & \\
\hline Hydrilla verticillata & (Low et al. 1993) & & & 198.00 & \\
\hline Algae Gelidium & (Vilar et al. 2007) & & & 171.00 & \\
\hline Ulva lactuca & (El Sikaily et al. 2006) & & & 40.20 & \\
\hline Enteromorpha spp. & (Ncibi et al. 2009) & & & 274.00 & \\
\hline Waste red mud & (Namasivayam and Arasi 1997) & & & & 4.05 \\
\hline Waste orange peel & (Namasivayam et al. 1996) & & & & 22.44 \\
\hline Cellulose/magnetite/activated carbon composite & (Zhu et al. 2011) & & & & 66.09 \\
\hline Pentaclethra macrophylla bark & (Babalola et al. 2016c) & & & & 157.23 \\
\hline Malacantha alnifolia bark & (Babalola et al. 2016c) & & & & 800.00 \\
\hline Zea mays stalk sponge & (García-Rosales and Colín-Cruz 2010) & & 80.00 & & \\
\hline Tripolyphosphate-impregnated Kaolinite clay & (Unuabonah et al. 2007) & & 126.58 & & \\
\hline Soybean hulls & (Johns et al. 1998) & & 39.37 & & \\
\hline Palm shell & (Issabayeva et al. 2006) & & 95.20 & & \\
\hline Peanut husk & (Ricordel et al. 2001) & & 113.96 & & \\
\hline PSW & This study & 208.33 & 325.73 & 1498.42 & 266.67 \\
\hline PBCE & This study & 194.93 & 332.23 & 403.23 & 288.18 \\
\hline
\end{tabular}



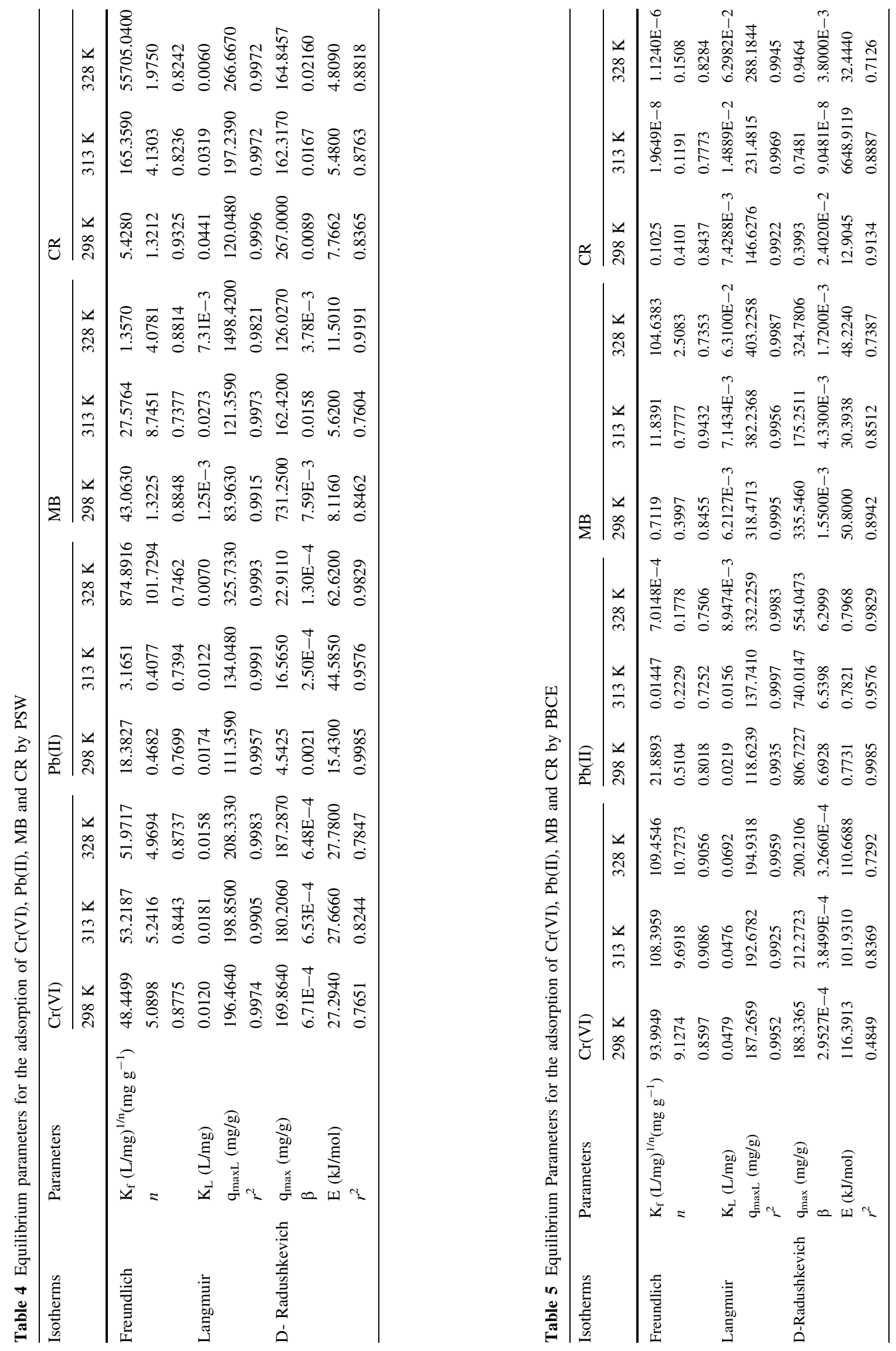
$q_{t}=K_{i p} t^{1 / 2}+\lambda$

$\ln K_{L}=-\frac{\Delta H^{o}}{R T}+\frac{\Delta S^{o}}{R}$

$\Delta G^{o}=-R T \ln K_{L}$

where $k_{f}$ is the Freundlich constant $(\mathrm{L} / \mathrm{mg})^{1 / \mathrm{n}}(\mathrm{mg} / \mathrm{g}), 1 / n$ is the empirical constant for adsorption affinity, $K_{L}$ is the Langmuir adsorption constant $(\mathrm{L} / \mathrm{mg}), q_{\max _{L}}$ is the $q_{e}$ for complete monolayer $(\mathrm{mg} / \mathrm{g}), q_{m}$ is the Dubinin-Radushkevich theoretical monolayer saturation capacity $(\mathrm{mg} / \mathrm{g}), \beta$ is the Dubinin-Radushkevich constant, $k_{1}$ is the pseudo-first order rate constant $(/ \mathrm{min}), k_{2}$ is the pseudo-second order rate constant $(\mathrm{g} / \mathrm{mg} \mathrm{min}), h_{a d s}$ is the initial sorption rate $(\mathrm{mg} / \mathrm{g} \mathrm{min}), R$ is the universal gas constant $(\mathrm{J} / \mathrm{mol} \mathrm{K}), T$ is the, absolute temperature $(\mathrm{K}), q_{t}$ is the amount of metal ion adsorbed at time $t(\mathrm{~min})$ by the biosorbents $(\mathrm{mg} / \mathrm{g}), K_{i p}$ is the Weber-Morris intraparticle diffusion constant $(\mathrm{mg} /$ $\left.\mathrm{g} \min ^{1 / 2}\right), \lambda$ is the boundary layer thickness, $\Delta H^{\circ}$ is the enthalpy of the adsorption process $(\mathrm{kJ} / \mathrm{mol}), \Delta S^{\circ}$ is the entropy of the adsorption process $(\mathrm{J} / \mathrm{mol} \mathrm{K}), \Delta G^{\circ}$ is the Gibb's free energy of the adsorption process $(\mathrm{kJ} / \mathrm{mol}), \varepsilon$ is the Polanyi potential and $E$ is the adsorption energy $(\mathrm{kJ} / \mathrm{mol})$.

\section{Results and discussion}

\section{Physicochemical analyses of PSW and PBCE}

Table 1 showed that the result from proximate analysis represented the percentages of crude protein, crude fat, crude fibre, ash, moisture content and carbohydrate to be similar for PSW and PBCE respectively.

Table 2 shows the FTIR vibration signals for PSW and $\mathrm{PBCE}$ respectively. For $\mathrm{PSW}$, the free $-\mathrm{OH}$ vibration stretch, $-\mathrm{N}-\mathrm{H}$ vibration stretch of amines, $-\mathrm{C}-\mathrm{H}$ vibration stretch of $\mathrm{CH}_{2}$ and $\mathrm{CH}_{3}$ of hemicelluloses, $-\mathrm{S}-\mathrm{H}$ vibration stretch of sulphydryl, $-\mathrm{C}=\mathrm{O}$ vibration stretch of ketones, lactones and ethers, $-\mathrm{C}-\mathrm{O}$ vibration stretch of ketones, lactones and ethers, and $-\mathrm{C}-\mathrm{O}$ vibration bend of ketones, lactones and ethers appeared at vibration frequencies of $3774,3445,2923,2368,1632,1385$ and $1037 \mathrm{~cm}^{-1}$. For $\mathrm{PBCE}$, the $-\mathrm{N}-\mathrm{H}$ vibration stretch of amines, $-\mathrm{S}-\mathrm{H}$ vibration stretch of sulphydryl, $-\mathrm{C}=\mathrm{O}$ vibration stretch of ketones, lactones and ethers, $-\mathrm{C}-\mathrm{O}$ vibration stretch of ketones, lactones and ethers, and $-\mathrm{C}-\mathrm{O}$ vibration bend of ketones, lactones and ethers appeared at vibration frequencies of $3434,2357,1632,1366$ and $1034 \mathrm{~cm}^{-1}$. The free $-\mathrm{OH}$ and $-\mathrm{C}-\mathrm{H}$ vibration stretches of $\mathrm{CH}_{3}$ and $\mathrm{CH}_{2}$ disappeared in PBCE, which resulted from the removal of hemicelluloses and crude fat during the preparation of PBCE (Babalola et al. 2016b, c). Furthermore, Fig. 1a and $b$ show the SEM images of PSW and PBCE. Figure 1a depicts a rough interwoven network of folded and flaky bioparticles, irregular and scattered on the biosorbent surface, while Fig. 1b represents a smooth surface, though cracked, less interwoven, less irregular and less scattered with bioparticles that look non flaky on the surface. The surface morphology of PSW might have accounted for the very high uptake of MB $\left(q_{\max _{L}}=1498.42 \mathrm{mg} / \mathrm{g}\right)$ over that obtained by PBCE, which was $\left(q_{\max _{L}}=403.23 \mathrm{mg} / \mathrm{g}\right)$ (Kumar et al. 2010; Babalola et al. 2016c).

\section{Effect of initial solution pH Study}

Solution $\mathrm{pH}$ is known to affect the degree of dissociation of various functional groups on biomass surface, the speciation and solubility of ions in aqueous media. Also, the solution $\mathrm{pH}$ of an adsorptive system exerts sharp influence on the sequestration of metals and dyes, presumably due to its effect on the surface properties of the biomass and ionisation/dissociation of the adsorbate (Deng et al. 2007; Kumar et al. 2010; Omorogie et al. 2016b; Lian et al. 2013).

The solution $\mathrm{pH}$ of maximum adsorption of $\mathrm{Cr}(\mathrm{VI})$, $\mathrm{Pb}(\mathrm{II}), \mathrm{MB}, \mathrm{CR}$ by PSW and PBCE were 3.0, 6.0, 12.0, 2.0 and 3.0, 7.0, 12.0, 2.0 respectively (Fig. $2 \mathrm{a}$ and b). The maximum uptake of $\mathrm{Cr}(\mathrm{VI})$ at $\mathrm{pH}$ value of 3.0 was the fact that from $\mathrm{pH}$ range $2.0-7.0$, the dominant forms of $\mathrm{Cr}(\mathrm{VI})$
Table 6 Kinetic Parameters for the adsorption of $\mathrm{Cr}(\mathrm{VI}), \mathrm{Pb}(\mathrm{II})$, $\mathrm{MB}$ and $\mathrm{CR}$ by PSW

\begin{tabular}{llllll}
\hline Kinetic models & Parameters & $\mathrm{Cr}(\mathrm{VI})$ & $\mathrm{Pb}(\mathrm{II})$ & $\mathrm{MB}$ & $\mathrm{CR}$ \\
\hline Pseudo-1st order & $\mathrm{k}_{1}(/ \mathrm{min})$ & 0.01984 & 5.2335 & 0.01477 & 0.03643 \\
& $\mathrm{q}_{\mathrm{e}}(\mathrm{mg} / \mathrm{g})$ & 97.7350 & 1.0198 & 186.6290 & 84.0103 \\
& $r^{2}$ & 0.9825 & 0.8981 & 0.8410 & 0.8182 \\
Pseudo-2nd order & $\mathrm{k}_{2}(\mathrm{~g} / \mathrm{mg} \mathrm{min})$ & $5.81 \mathrm{E}-4$ & $3.169 \mathrm{E}-4$ & $1.571 \mathrm{E}-4$ & $0.104 \mathrm{E}-4$ \\
& $\mathrm{q}_{\mathrm{e}}(\mathrm{mg} / \mathrm{g})$ & 127.0648 & 389.1050 & 204.0816 & 107.9914 \\
& $r^{2}$ & 0.9972 & 0.9905 & 0.9998 & 0.9993 \\
Morris-Weber & $\mathrm{k}_{\mathrm{ip}} \mathrm{t}^{1 / 2}$ & 10.1222 & 34.3099 & 17.9360 & 29.9020 \\
Intraparticle diffusion & $\hat{\lambda}$ & 15.3525 & 73.2829 & 14.5337 & 33.0173 \\
& $r^{2}$ & 0.9485 & 0.7461 & 0.9259 & 0.8496 \\
\hline
\end{tabular}


Table 7 Kinetic Parameters for the adsorption of $\mathrm{Cr}(\mathrm{VI}), \mathrm{Pb}$ (II), $\mathrm{MB}$ and $\mathrm{CR}$ by PBCE

\begin{tabular}{llllll}
\hline Kinetic models & Parameters & $\mathrm{Cr}(\mathrm{VI})$ & $\mathrm{Pb}(\mathrm{II})$ & $\mathrm{MB}$ & $\mathrm{CR}$ \\
\hline Pseudo-1st order & $\mathrm{k}_{1}(/ \mathrm{min})$ & 0.1408 & $1.7290 \mathrm{E}-2$ & $9.9300 \mathrm{E}-3$ & $8.6900 \mathrm{E}-3$ \\
& $\mathrm{q}_{\mathrm{e}}(\mathrm{mg} / \mathrm{g})$ & 22.1889 & 231.0421 & 178.6592 & 399.5544 \\
& $r^{2}$ & 0.9347 & 0.7400 & 0.8904 & 0.8690 \\
Pseudo-2nd order & $\mathrm{k}_{2}(\mathrm{~g} / \mathrm{mg} \mathrm{min})$ & $1.5200 \mathrm{E}-2$ & $2.0493 \mathrm{E}-4$ & $9.9582 \mathrm{E}-5$ & $3.3712 \mathrm{E}-5$ \\
& $\mathrm{q}_{\mathrm{e}}(\mathrm{mg} / \mathrm{g})$ & 23.5905 & 408.1633 & 197.6285 & 413.2231 \\
& $r^{2}$ & 0.9997 & 0.9991 & 0.9995 & 0.9990 \\
Morris-Weber & $\mathrm{k}_{\mathrm{ip}} \mathrm{t}^{1 / 2}$ & 16.6692 & 36.4511 & 14.0891 & 27.0752 \\
Intraparticle diffusion & $t$ & 15.3096 & 53.5724 & 7.4308 & 30.7415 \\
& $r^{2}$ & 0.9081 & 0.7731 & 0.9385 & 0.9755 \\
\hline
\end{tabular}

were $\mathrm{Cr}_{2} \mathrm{O}_{7}{ }^{2-}$ and $\mathrm{HCrO}_{4}{ }^{-}$ions, and $\mathrm{CrO}_{4}{ }^{2-}$ at lower $\mathrm{pH}$ values prevailed in aqueous solution. At $\mathrm{pH}$ 3.0, the PSW and $\mathrm{PBCE}$ get more protonated, thereby reducing competition and more $\mathrm{Cr}(\mathrm{VI})$ bind to their surfaces by electrostatic attraction ( $\mathrm{Li}$ and Bowman 2001). Furthermore, the presence of $\mathrm{Cr}_{2} \mathrm{O}_{7}{ }^{2-}$ and $\mathrm{HCrO}_{4}{ }^{-}$species in solution at this $\mathrm{pH}$ range also enhance the greater uptake $\mathrm{Cr}(\mathrm{VI})$.

The phenomenon of complexation could take place on PSW and PBCE surfaces, especially for the carboxyl group $(-\mathrm{C}=\mathrm{O})$ or the hydroxyl group $(-\mathrm{OH})$ of these biosorbents. It is understood that some functional groups probably took part in the removal of $\mathrm{Cr}(\mathrm{VI}), \mathrm{Pb}(\mathrm{II}), \mathrm{MB}$ and $\mathrm{CR}$ due to the nature of the active sites on PSW and PBCE.

At $\mathrm{pH}>6.0$, precipitation is the main mechanism of $\mathrm{Pb}$ (II) ion removal and this can be attributed to the formation of $\mathrm{Pb}(\mathrm{OH})_{2}$ precipitate. Also, the presence of the hydroxylated species at $(\mathrm{pH} \leq 7.0)$ impeded further uptake of Pb(II) by PSW and PBCE (García-Rosales and ColínCruz 2010). This was responsible for the maximum uptake of $\mathrm{Pb}$ (II) ion by $\mathrm{PSW}$ and $\mathrm{PBCE}$ at $\mathrm{pH}<7.0$.

The maximum uptake of MB by PSW and PBCE at $\mathrm{pH}$ 12.0 was due to the fact that $\mathrm{H}^{+}$competed less with $\mathrm{MB}$ for PSW and PBCE surfaces. Reverse is the case at acidic $\mathrm{pH}$, the PSW and PBCE were protonated and less MB were adsorbed onto PSW and PBCE by electrostatic attraction respectively. The high removal of MB onto PSW and PBCE was due to the low proton densities on the adsorbent surfaces at pH 12.0 (Babalola et al. 2016c).

The maximum uptake of CR by PSW and PBCE was achieved at $\mathrm{pH}$ 2.0. The largest amounts of $\mathrm{CR}$ adsorbed by PSW and PBCE were expected due to an increase in the proton densities of PSW and PBCE at $\mathrm{pH}$ 2.0. This made the anionic CR molecules to bind easily to their surfaces (Unuabonah et al. 2007; Babalola et al. 2016c).

\section{Effect of adsorbent dose}

The amount $q_{e}(\mathrm{mg} / \mathrm{g})$ of $\mathrm{Cr}(\mathrm{VI}), \mathrm{Pb}(\mathrm{II}), \mathrm{MB}, \mathrm{CR}$ adsorbed by PSW and PBCE decreased from 118.86-15.25, $355.68-18.85, \quad 156.97-6.970, \quad 275.00-5.42$ and
149.98-16.20, 358.00-18.74, 145.83-9.78, 270.63-10.19 respectively with increase in adsorbent dose from 10 to $200 \mathrm{mg}$. This is due to decrease in specific surface area and increase in diffusion path length resulting from agglomeration or aggregation of the adsorbent particles as the dose increased (Unuabonah et al. 2007) (see Fig. 3a, b).

\section{Effect of contact time}

The amount $q_{t}(\mathrm{mg} / \mathrm{g})$ of $\mathrm{Cr}(\mathrm{VI}), \mathrm{Pb}(\mathrm{II}), \mathrm{MB}, \mathrm{CR}$ adsorbed by PSW and PBCE increased from 25.5-117.15, 31.7$356.63,7.75-163.05,3.75-275.33$ and 5.43-125.00, 46.50$359.20,2.50-135.55,8.15-266.25$ respectively as time $t$ (min) also increased from 1 to 120 . This is attributed to the fact that the adsorption processes were fast as sorbate ions $(\mathrm{Cr}(\mathrm{VI}), \mathrm{Pb}(\mathrm{II}), \mathrm{MB}$ and $\mathrm{CR})$ diffused from the bulk aqueous solution to the unoccupied sites on the exterior surface of PSW and PBCE. Thereafter, these active sites on PSW and PBCE exterior surfaces got filled and become saturated as the sorbate ions diffused their interior pores comprising cationic functional groups as contact time increased from 1 to 120 min (Wang and Yan 2011). Figures $4 \mathrm{a}$ and $\mathrm{b}$ show the plots of the amount of $\mathrm{Cr}(\mathrm{VI})$, $\mathrm{Pb}(\mathrm{II}), \mathrm{MB}$ and $\mathrm{CR}$ adsorbed, $q_{t}(\mathrm{mg} / \mathrm{g})$ by PSW and PBCE against time $t(\mathrm{~min})$ respectively.

\section{Adsorption equilibrium, kinetics and thermodynamics}

Adsorption isotherm models play cogent role in determining the maximum uptake capacity of adsorbent with respect to its effectiveness, efficiency and economic viability (Unuabonah et al. 2007; Omorogie et al. 2016b). Optimisation design for the adsorption process involves the maximum performance evaluation of the sorbents for sequestering $\mathrm{Cr}(\mathrm{VI}), \mathrm{Pb}(\mathrm{II}), \mathrm{MB}$ and $\mathrm{CR}$ in this research. Various equilibrium models like Freundlich, Langmuir and Dubinin-Radushkevich isotherms were used to analyse the equilibrium data obtained from the adsorption of $\mathrm{Cr}(\mathrm{VI})$, $\mathrm{Pb}(\mathrm{II}), \mathrm{MB}$ and $\mathrm{CR}$ by PSW and $\mathrm{PBCE}$ respectively. It was 


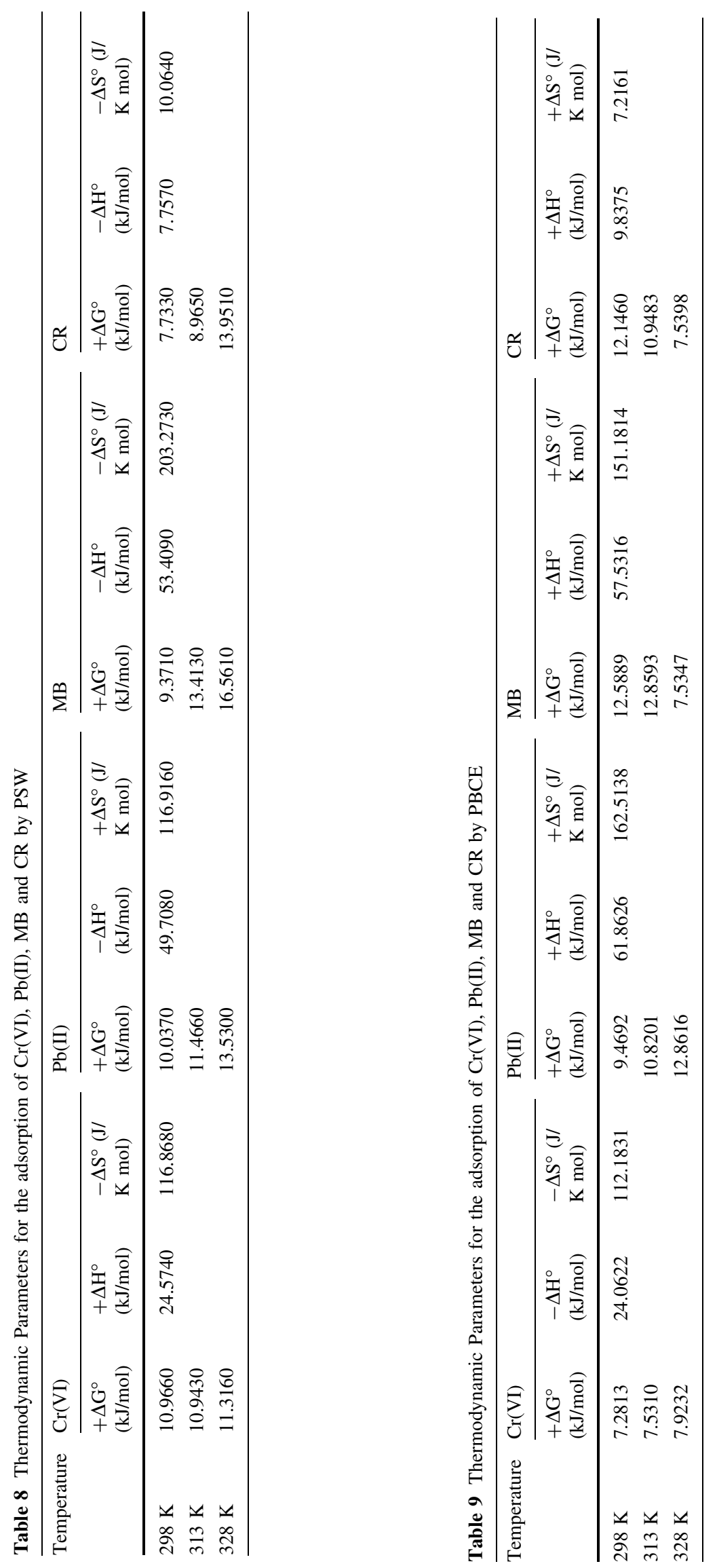


observed that Langmuir isotherm best fitted the equilibrium data.

Table 3 shows a list of various adsorbents and their adsorption capacities (mg/g) in literature for $\mathrm{Cr}(\mathrm{VI}), \mathrm{Pb}(\mathrm{II})$, $\mathrm{MB}$ and $\mathrm{CR}$.

For PSW, the saturated monolayer capacities, $q_{\max _{L}}$, for the adsorption of $\mathrm{Cr}(\mathrm{VI}), \mathrm{Pb}(\mathrm{II}), \mathrm{MB}$ and $\mathrm{CR}$ were 196.46-208.33 mg/g, 111.36-325.73 mg/g, 83.86-1498.42 $\mathrm{mg} / \mathrm{g}$ and $120.05-266.67 \mathrm{mg} / \mathrm{g}$ as temperature increased from 298 to $328 \mathrm{~K}$ respectively (see Table 4 ).

(a)

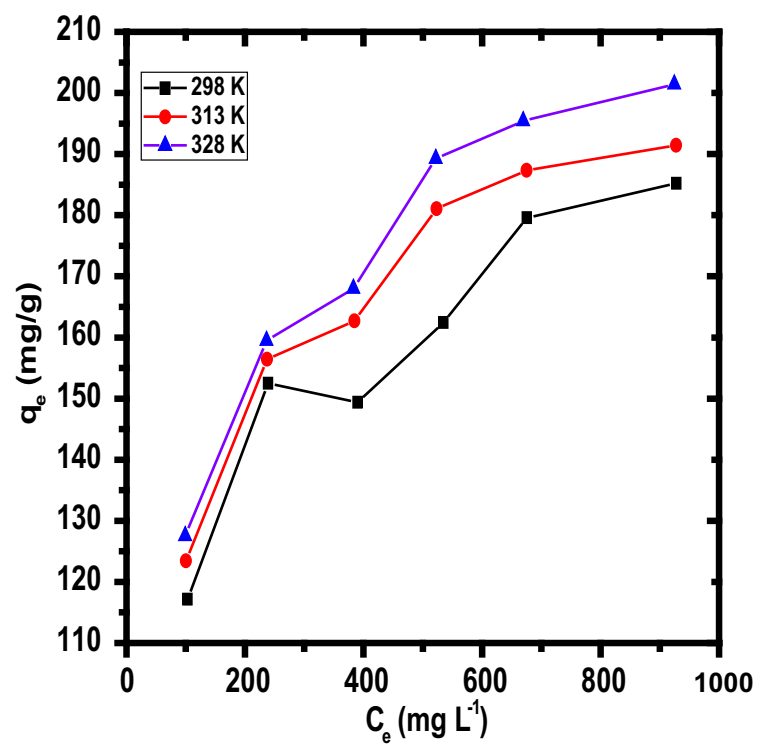

(c)

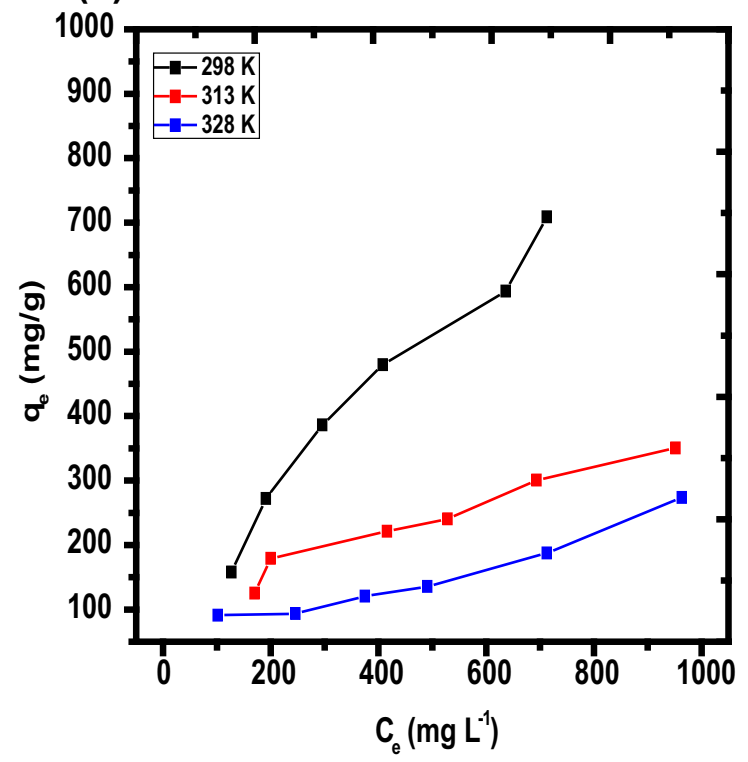

Fig. 5 The plots of the amount of a $\mathrm{Cr}(\mathrm{VI})$ adsorbed, $q_{e}(\mathrm{mg} / \mathrm{g})$ by PSW against equilibrium concentration, $C_{e}(\mathrm{mg} / \mathrm{L})$ different temperatures, b $\mathrm{Pb}$ (II) adsorbed, $q_{e}(\mathrm{mg} / \mathrm{g})$ by $\mathrm{PSW}$ against equilibrium concentration, $C_{e}(\mathrm{mg} / \mathrm{L})$ different temperatures, c MB adsorbed,
For PBCE, the saturated monolayer capacities $q_{\max _{L}}$, for the adsorption of $\mathrm{Cr}(\mathrm{VI}), \mathrm{Pb}(\mathrm{II}), \mathrm{MB}$ and $\mathrm{CR}$ were 187.27$194.93 \mathrm{mg} / \mathrm{g}, 118.62-332.23 \mathrm{mg} / \mathrm{g}, 318.47-403.23 \mathrm{mg} / \mathrm{g}$ and $146.63-288.18 \mathrm{mg} / \mathrm{g}$ as temperature increased from 298 to $328 \mathrm{~K}$ respectively (see Table 5).

The increase in the adsorption of $\mathrm{Cr}(\mathrm{VI}), \mathrm{Pb}(\mathrm{II}), \mathrm{MB}$ and CR by PSW and PBCE could be attributed to increase in the rate of reaction and collision of reacting particles as temperature increased. It also indicates that the mass transfer and diffusion of sorbate from the bulk solution

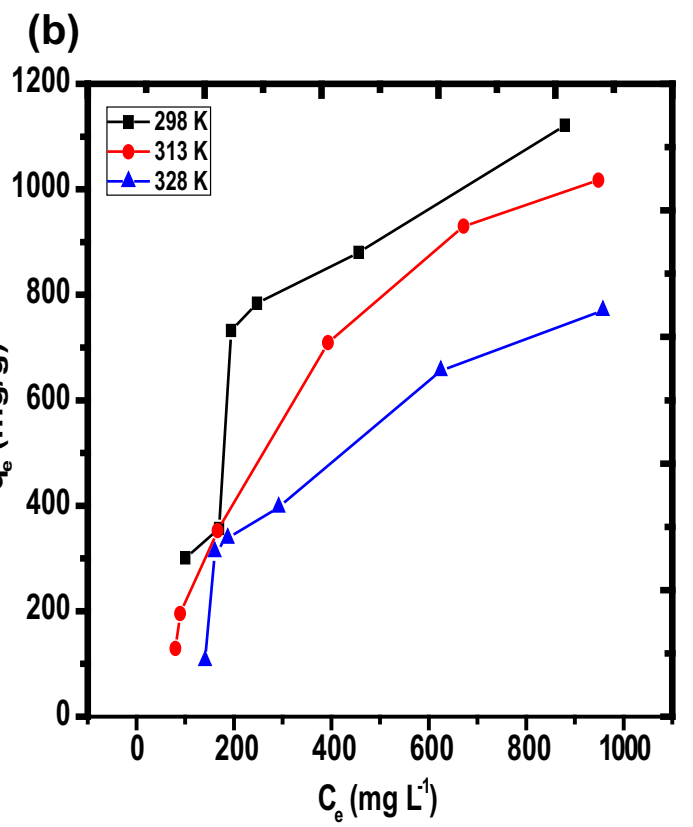

(d)

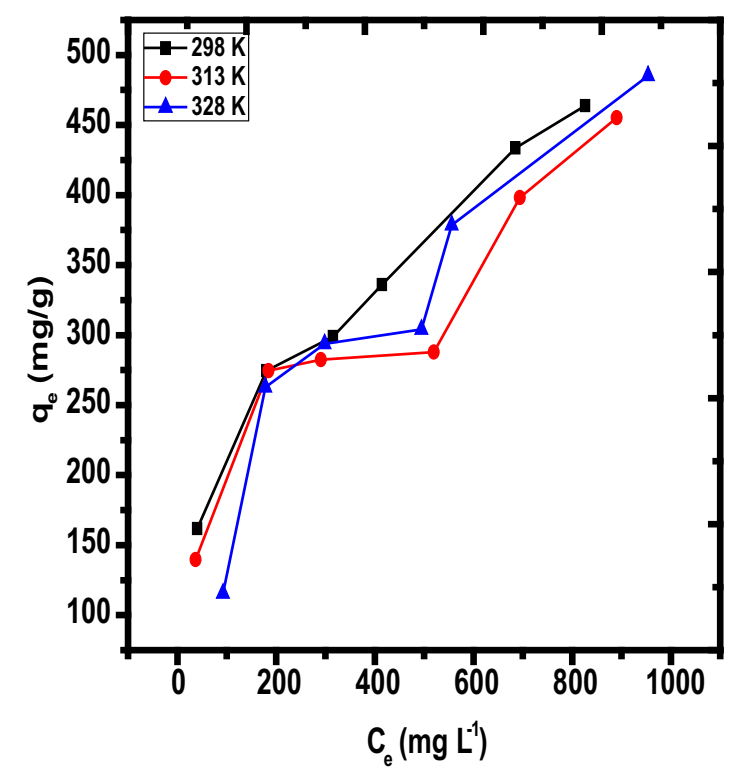

$q_{e}(\mathrm{mg} / \mathrm{g})$ by PSW against equilibrium concentration, $C_{e}(\mathrm{mg} / \mathrm{L})$ different temperatures and $\mathbf{d}$ CR adsorbed, $q_{e}(\mathrm{mg} / \mathrm{g})$ by PSW against equilibrium concentration, $C_{e}(\mathrm{mg} / \mathrm{L})$ at different temperatures 
(a)

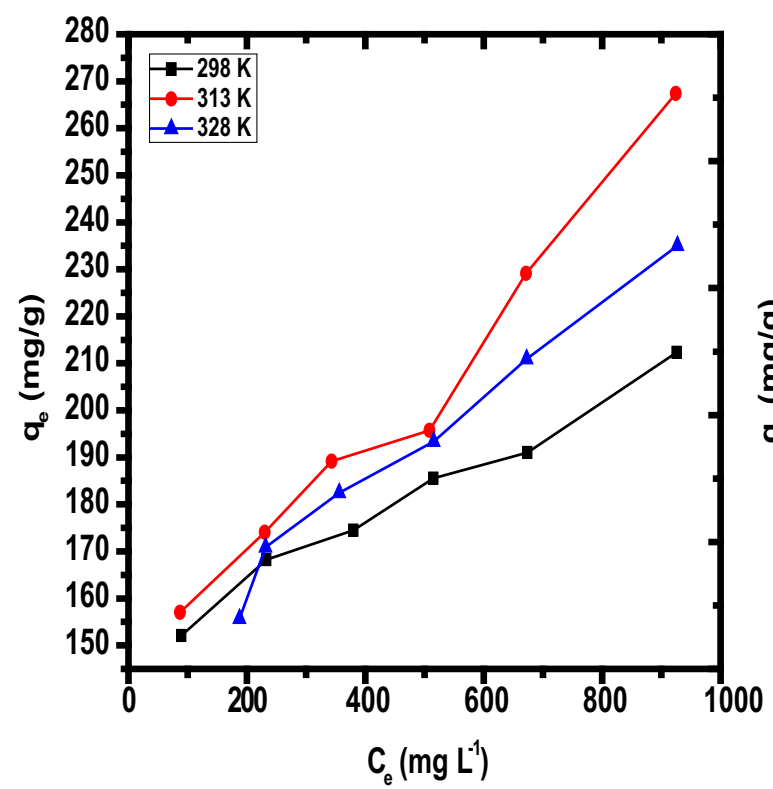

(c)

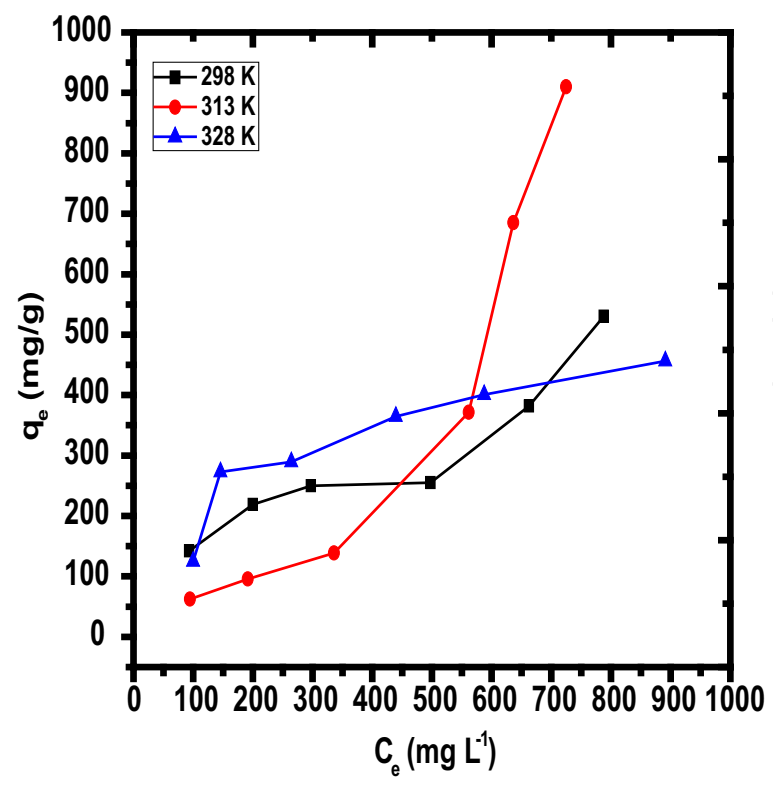

Fig. 6 The plots of the amount of a $\mathrm{Cr}(\mathrm{VI})$ adsorbed, $q_{e}(\mathrm{mg} / \mathrm{g})$ by PBCE against equilibrium concentration, $C_{e}(\mathrm{mg} / \mathrm{L})$ different temperatures, b $\mathrm{Pb}(\mathrm{II})$ adsorbed, $q_{e}(\mathrm{mg} / \mathrm{g})$ by $\mathrm{PBCE}$ against equilibrium concentration, $C_{e}(\mathrm{mg} / \mathrm{L})$ different temperatures, c $\mathrm{MB}$ adsorbed,

onto the active sites in the biosorbent was faster at higher temperatures (Lian et al. 2013).

The values of $8 \geq \mathrm{E}>16 \mathrm{~kJ} / \mathrm{mol}$ for the sequestration of $\mathrm{Cr}(\mathrm{VI})$ and $\mathrm{Pb}(\mathrm{II})$ by $\mathrm{PSW}$ indicated that these processes were chemisorptive at all temperatures. The values of $\mathrm{E}<8 \mathrm{~kJ} / \mathrm{mol}$ at $313 \mathrm{~K}$ (physisorption), and $\mathrm{E}>8 \mathrm{~kJ} / \mathrm{mol}$ at 298 and $328 \mathrm{~K}$ (chemisorption) for the removal of $\mathrm{MB}$ by PSW. Also, the values of $\mathrm{E}<8 \mathrm{~kJ} / \mathrm{mol}$ obtained for the (b)

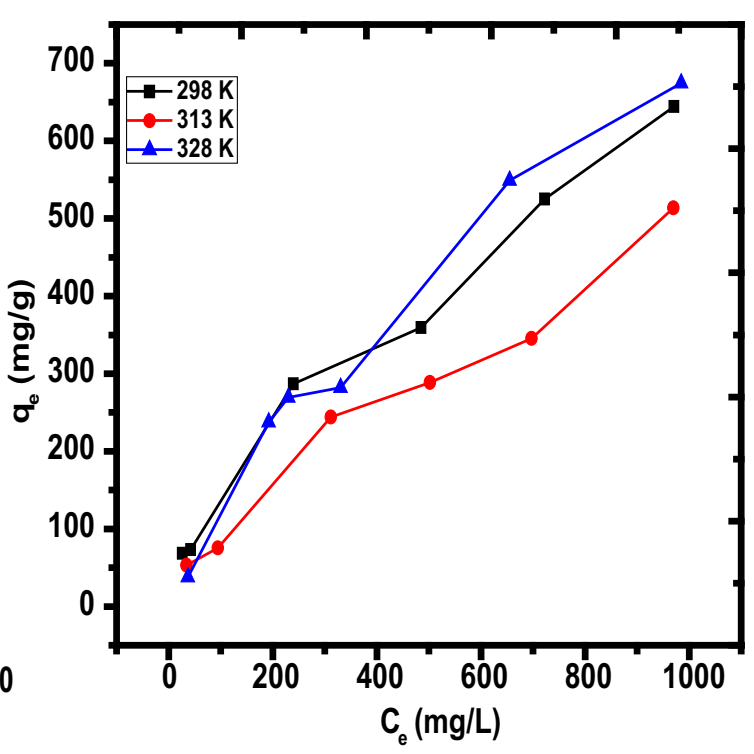

(d)

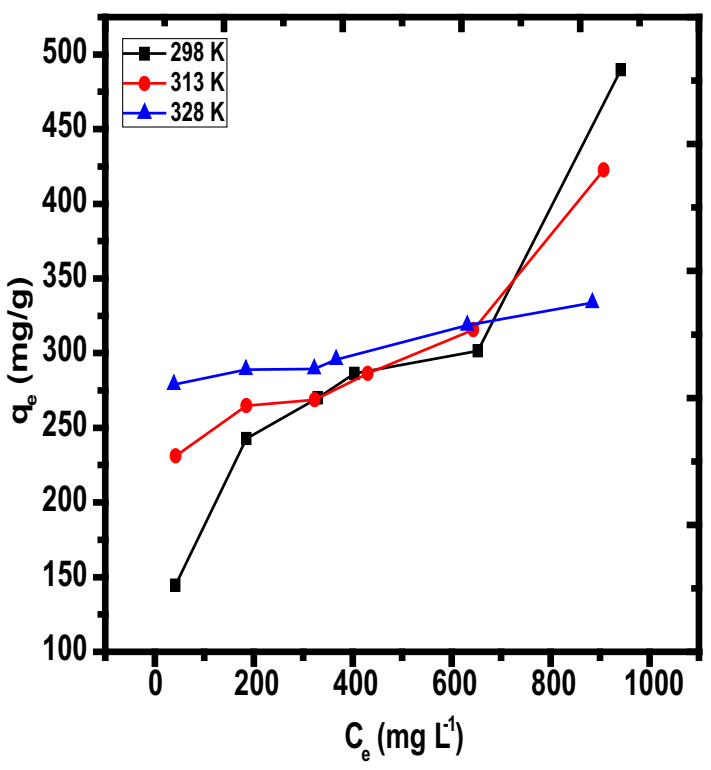

$q_{e}(\mathrm{mg} / \mathrm{g})$ by $\mathrm{PBCE}$ against equilibrium concentration, $C_{e}(\mathrm{mg} / \mathrm{L})$ different temperatures and $\mathbf{d} \mathrm{CR}$ adsorbed, $q_{e}(\mathrm{mg} / \mathrm{g})$ by PBCE against equilibrium concentration, $C_{e}(\mathrm{mg} / \mathrm{L})$ different temperatures

sequestration of CR by PSW showed physisorption at all temperatures (see Table 4).

The values of $8 \geq \mathrm{E}<16 \mathrm{~kJ} / \mathrm{mol}$ for the removal of $\mathrm{Cr}(\mathrm{VI})$ by PBCE signified chemisorption. It is also interesting to note that the removal of $\mathrm{Pb}(\mathrm{II})$ by $\mathrm{PBCE}$ had the values of $\mathrm{E}<8 \mathrm{~kJ} / \mathrm{mol}$, which indicated that the adsorption processes were physisorptive at all temperatures. The removal of $\mathrm{MB}$ and $\mathrm{CR}$ by $\mathrm{PBCE}$ had the values of 
$8 \geq \mathrm{E}<16 \mathrm{~kJ} / \mathrm{mol}$, which were indicative of chemisorption (see Table 5).

In order to understand the controlling mechanism(s), mass transfer, intraparticle diffusion and dynamics of the adsorption process, kinetic data were fitted into pseudo-first order, pseudo-second order and Morris-Weber intraparticle diffusion kinetic models. Pseudo-second order kinetic model best fits the kinetic data (see Tables 6, 7). The pseudo-second order rate constants $k_{2}$ for the adsorption of $\mathrm{Cr}(\mathrm{VI}), \mathrm{Pb}(\mathrm{II}), \mathrm{MB}, \mathrm{CR}$ by PSW and PBCE were 5.81E-4, $3.17 \mathrm{E}-4,1.57 \mathrm{E}-4,0.10 \mathrm{E}-4$ and $1.52 \mathrm{E}-2,2.05 \mathrm{E}-4$, $9.96 \mathrm{E}-5$ and $3.37 \mathrm{E}-5$ respectively. These values were smaller than those of pseudo-first order rate constants $k_{1}$.

The Morris-Weber intraparticle diffusion kinetic model for the adsorption of $\mathrm{Cr}(\mathrm{VI}), \mathrm{Pb}(\mathrm{II}), \mathrm{MB}, \mathrm{CR}$ by PSW and PBCE showed that the values of the constant $\lambda$, which were the thickness of the boundary layer were $>0$, and hence did not pass through the origin. This implied that other diffusion processes like pore diffusion and film diffusion, apart from intraparticle diffusion took part in the adsorption process (Babalola et al. 2016a).

Thermodynamic studies indicated that all the values of Gibb's free energy change $\left(\Delta G^{o}\right)$ for the adsorption of $\mathrm{Cr}(\mathrm{VI}), \mathrm{Pb}(\mathrm{II}), \mathrm{MB}$ and $\mathrm{CR}$ by PSW were positive. This suggested the non feasibility and non spontaneity of the system. The values of enthalpy change $\left(\Delta H^{o}\right)$ for the adsorption of $\mathrm{Pb}(\mathrm{II}), \mathrm{MB}$ and $\mathrm{CR}$ by $\mathrm{PSW}$ were negative, indicating the exothermic nature of the system. But, the value of enthalpy change $\left(\Delta H^{o}\right)$ for the adsorption of $\mathrm{Cr}(\mathrm{VI})$ by PSW was positive, indicating the endothermic nature the system. The values of entropy change $\left(\Delta S^{o}\right)$ for the adsorption of $\mathrm{Cr}(\mathrm{VI}), \mathrm{MB}$ and $\mathrm{CR}$ by PSW were negative, showing decrease in the degree of chaos of the system. This signified decrease in the disorderliness of the sorbent/sorbate interface. Also, the value of entropy change $\left(\Delta S^{o}\right)$ for the adsorption of $\mathrm{Pb}$ (II) was positive, showing increase in the degree of chaos of the system. This signified increase in the disorderliness of the sorbent/sorbate interface. Moreover, all the values of $\Delta G^{o}$ for the adsorption of $\mathrm{Cr}(\mathrm{VI}), \mathrm{Pb}(\mathrm{II}), \mathrm{MB}$ and $\mathrm{CR}$ by PBCE were also positive, showing the non feasibility and non spontaneity of the system. The values of $\Delta H^{o}$ for the adsorption of $\mathrm{Pb}(\mathrm{II}), \mathrm{MB}$ and $\mathrm{CR}$ by $\mathrm{PBCE}$ were positive, indicating that the system was endothermic. But, the value of $\Delta H^{o}$ for the adsorption of $\mathrm{Cr}(\mathrm{VI})$ by PBCE was negative, showing that the system was exothermic. The values of $\Delta S^{o}$ for the adsorption of $\mathrm{Pb}(\mathrm{II}), \mathrm{MB}$ and $\mathrm{CR}$ by PBCE were positive, showing increase in the degree of chaos of the system. But, the value of $\Delta S^{o}$ for the adsorption of $\mathrm{Cr}(\mathrm{VI})$ by $\mathrm{PBCE}$ was negative, indicating decrease in the degree of chaos of the system (see Tables 8, 9). Figures $5 \mathrm{a}-\mathrm{d}$ and $6 \mathrm{a}-\mathrm{d}$ show the plots of the amount of $\mathrm{Cr}(\mathrm{VI}), \mathrm{Pb}(\mathrm{II}), \mathrm{MB}$ and $\mathrm{CR}$ adsorbed, $q_{e}(\mathrm{mg} / \mathrm{g})$ by PSW and PBCE against equilibrium concentration, $C_{e}$ $(\mathrm{mg} / \mathrm{L})$ at different temperatures respectively.

\section{Conclusion}

This work explored the adsorptive capacities of PSW and PBCE for the removal of $\mathrm{Cr}(\mathrm{VI}), \mathrm{Pb}(\mathrm{II}), \mathrm{MB}$ and $\mathrm{CR}$ from aqua system. Physicochemical analyses, equilibrium, kinetic and thermodynamic data established that PSW and PBCE biosorbents showed viable performance for futuristic applications in the treatment of polluted and industrial wastewaters.

\section{References}

Al-Degs YS, El-Barghouthi MI, Khraisheh MA, Ahmad MN, Allen SJ (2004) Effect of surface area, micropores, secondary micropores and mesopores volumes of activated carbons on reactive dyes adsorption from solution. Sep Sci Technol 39:97-111

Aoyama M, Kishino M, Jo T-S (2005) Adsorption of $\mathrm{Cr}(\mathrm{VI})$ on Japanese cedar bark. Sep Sci Technol 39:1149-1162

Babalola JO, Omorogie MO, Babarinde AA, Unuabonah EI, Oninla VO (2016a) Optimization of the biosorption of $\mathrm{Cr}^{3+}, \mathrm{Cd}^{2+}$ and $\mathrm{Pb}^{2+}$ using new biowaste: Zea mays seed chaff. Environ Eng Manag J 15:1571-1580

Babalola JO, Koiki BA, Eniayewu Y, Salimonu A, Olowoyo JO, Oninla VO, Alabi HA, Ofomaja AE, Omorogie MO (2016b) Adsorption efficacy of Cedrela odorata seed waste for dyes: non linear fractal kinetics and non linear equilibrium studies. J Environ Chem Eng 4(3):3527-3536

Babalola JO, Olowoyo JO, Durojaiye AO, Olatunde AM, Unuabonah EI, Omorogie MO (2016c) Understanding the removal and regeneration potentials of biogenic wastes for toxic metals and organic dyes. J Taiwan Inst Chem Eng 58:490-499

Barnhart J (1997) Occurrences, uses, and properties of chromium. Regul Toxicol Pharmacol 26(1):S3-S7

Campbell-Platt G (1980) Africa locust bean (Parkia species) and its West African fermented food product, dawadawa. Eco Food Nutr 9:123-131

Daneshvar N, Salari D, Aber S (2002) Chromium adsorption and $\mathrm{Cr}(\mathrm{VI})$ reduction to trivalent chromium in aqueous solutions by soya cake. J Hazard Mater 94:49-61

Deng B, Alan TS (1996) Surface-catalyzed Chromium(VI) reduction: reactivity comparisons of different organic reductants and different oxide surfaces. Environ Sci Technol 30:2484-2494

Deng L, Su Y, Su H, Wang X, Zhu X (2007) Sorption and desorption of Lead(II) from wastewater by green algae Cladophora fascicularis. J Hazard Mater 143:220-225

Dubinin MM (1960) The potential theory of adsorption of gases and vapors for adsorbents with energetically non-uniform surface. Chem Rev 60:235-266

Dupont L, Guillon E (2003) Removal of hexavalent chromium with a lignocellulosic substrate extracted from wheat bran. Environ Sci Technol 37:4235-4241

El Sikaily A, Khaled A, El Nemr A, Abdelwahab O (2006) Removal of methylene blue from aqueous solution by marine green alga Ulva lactuca. Chem Ecol 22(2):149-157

Freundlich HMF (1906) Over the adsorption in solution. J Phys Chem $57: 385-470$ 
Fu Y, Viraraghavan T (2000) Removal of a dye from an aqueous solution by the fungus Aspergillus niger. Water Qual Res J Can 35(1):95-111

García-Rosales G, Colín-Cruz A (2010) Adsorption of lead by maize (Zea mays) stalk sponge. J Environ Manag 91:2079-2086

Gercel O, Gercel HF (2007) Adsorption of lead(II) ions from aqueous solutions by activated carbon prepared from biomass plant material of Euphorbia rigida. Chem Eng J 132:289-297

Gupta GS, Shukla SP, Prasad G, Singh VN (1992) China clay as an adsorbent for dye house wastewater. Environ Technol 13:925-936

Hagos TH (1962) A revision of genius Parkia in Africa. Acta Bot Nearthandica 11:231-265

Hall LS, Krausmaman PR, Morrison ML (1991) The habitat concept and a plea for standard technology. Wildl Soc Bull 25(1):173-182

Ho YS, McKay G (1999) Batch lead(II) removal from aqueous solution by peat: equilibrium and kinetics. Trans Chem B 77:165-173

Ho YS, Ng JCY, Mckay G (2000) Kinetics of pollutant sorption by biosorbents: review. Sep Purif Methods 29:186-232

Irvine FR (1961) Woody plants of Ghana. Oxford University Press, London

Issabayeva G, Aroua MK, Sulaiman NMN (2006) Removal of lead from aqueous solutions on palm shell activated carbon. Bioresour Technol 97:350-355

Johns MM, Marshall WE, Toles CA (1998) Agricultural by-products as granular activated carbons for adsorbing dissolved metals and organics. J Chem Technol Biotechnol 71:131-140

Krishnani KK, Meng X, Christodoulatos C, Boddu VM (2008) Adsorption mechanism of nine different heavy metals onto biomatrix from rice husk. J Hazard Mater 153:1222-1234

Kumar PS, Ramalingam S, Senthamarai C, Niranjanaa M, Vijayalakshmi P, Sivanesan S (2010) Adsorption of dye from aqueous solution by cashew nut shell: studies on equilibrium isotherm, kinetics and thermodynamics of interactions. Desalination 261:52-60

Lagergren S (1898) Zur theorie der sogenannten adsorption geloster stoffe. Kungliga SVenska Vetenskapsakademiens. Handlingar Band 24:1-39

Langmuir I (1916) The adsorption of gases on plane surfaces of glass, mica and platinum. J Am Chem Soc 40:1361-1403

Li Z, Bowman RS (2001) Retention of inorganic oxyanions by organo-kaolinite. Water Res 35:3771-3776

Li K, Wang X (2009) Adsorptive removal of $\mathrm{Pb}(\mathrm{II})$ by activated carbon prepared from Spartina alterniflora: equilibrium, kinetics and thermodynamics. Bioresour Technol 100:2810-2815

Lian L, Cao X, Wu Y, Lou D, Han D (2013) Synthesis of organofunctionalized magnetic microspheres and application for anionic dye removal. J Taiwan Inst Chem Eng 44:52-60

Low KS, Lee CK, Heng LL (1993) Sorption of basic dyes by Hydrilla verticillata. Environ Technol 14:115-124

Ma H, Zhuo Q, Wang B (2009) Electro-catalytic degradation of methylene blue wastewater assisted by $\mathrm{Fe}_{2} \mathrm{O}_{3}$-modified kaolin. Chem Eng J 155:248-253

Mahir A, Özkan D, Mehmet D (2004) Removal of acid yellow49 from aqueous solution by adsorption. Fresenius Environ Bull 13:1112-1121

Mane VS, Mall ID, Srivastava VC (2007) Kinetic and equilibrium isotherm studies for the adsorptive removal of Brilliant Green dye from aqueous solution by rice husk ash. J Environ Manag $84: 390-400$

Marjanovic V, Lazarevic S, Jankovic-Castvan I, Potkonjak B, Janackovic D, Petrovic R (2011) Chromium (VI) removal from aqueous solutions using mercaptosilane functionalized sepiolites. Chem Eng J 166:198-206
Marungrueng K, Pavasant P (2007) High performance biosorbent (Caulerpa lentillifera) for basic dye removal. Bioresour Technol 98:1567-1572

Maurya NS, Mittal AK, Cornel P, Rother E (2006) Adsorption of dyes using dead macro fungi: effect of dye structure, ionic strength and $\mathrm{pH}$. Bioresour Technol 97:512-521

Minero C, Lucchiari M, Vione D, Maurino V (2005) Fe(III)-enhanced sonochemical degradation of methylene blue in aqueous solution. Environ Sci Technol 39:8936-8942

Mitra P, Sarkar D, Chakrabarti S, Dutta BK (2011) Reduction of hexa-valent chromium with zero-valent iron: batch kinetic studies and rate model. Chem Eng J 171:54-60

Namasivayam C, Arasi DJSE (1997) Removal of congo red from wastewater by adsorption onto waste red mud. Chemosphere 34:401-417

Namasivayam C, Muniasamy N, Gayathri K, Rani M, Ranganathan K (1996) Removal of dyes from aqueous solutions by cellulosic waste orange peel. Bioresour Technol 57:37-43

Ncibi MC, Hamissa AMB, Fathallah A, Kortas MH, Baklouti T, Mahjoub B, Seffen M (2009) Adsorptive uptake of methylene blue using Mediterranean green alga Enteromorpha spp. J Hazard Mater 170:1050-1055

Oguz E (2005) Adsorption characteristics and the kinetics of the $\mathrm{Cr}(\mathrm{VI})$ on the Thuja oriantalis. Coll Surf A Physicochem Eng Asp 252:121-128

Olu-Owolabi BI, Diagboya PN, Ebaddan WC (2012) Mechanism of $\mathrm{Pb}^{2+}$ removal from aqueous solution using a nonliving moss biomass. Chem Eng J 195:270-275

Omorogie MO, Babalola JO, Unuabonah EI, Gong JR (2012) Kinetics and thermodynamics of heavy metal ions sequestration onto novel Nauclea diderrichii seed biomass. Bioresour Technol 118:576-579

Omorogie MO, Babalola JO, Unuabonah EI, Gong JR (2014a) Solid phase extraction of hazardous metals from aqua system by nanoparticle-modified agrowaste composite adsorbents. J Environ Chem Eng 2(1):675-684

Omorogie MO, Babalola JO, Unuabonah EI, Gong JR (2014b) Hybrid materials from agrowaste and nanoparticles: implications on the kinetics of the adsorption of inorganic pollutants. Environ Technol 35(5):611-619

Omorogie MO, Babalola JO, Unuabonah EI, Gong JR (2015) New facile benign agrogenic-nanoscale titania material; remediation potential for toxic inorganic cations. J Water Proc Eng 5(1):95-100

Omorogie MO, Babalola JO, Unuabonah EI, Gong JR (2016a) Clean technology approach for the competitive binding of toxic metal ions onto $\mathrm{MnO}_{2}$ nano-bioextractant. Clean Techn Environ Policy 18(1):171-184

Omorogie MO, Babalola JO, Unuabonah EI, Song W, Gong JR (2016b) Efficient chromium abstraction from aqueous solution using a low-cost biosorbent: Nauclea diderrichii seed waste. J Saudi Chem Soc 20:49-57

Owlad M, Aroua MK, Wan Daud WMA (2010) Hexavalent chromium adsorption on impregnated palm shell activated carbon with polyethyleneimine. Bioresour Technol 101:5098-5103

Pagnanelli F, Mainelli S, Veglio F, Toro L (2003) Heavy metal removal by olive pomace: biosorbent characterization and equilibrium modeling. Chem Eng Sci 58:4709-4717

Ponnusami V, Kritika V, Madhuram R, Srivastava SN (2007) Adsorption of reactive dye using acid-treated rice husk: factorial design analysis. J Hazard Mater 142:397-403

Poopal AC, Laxman RS (2009) Studies on biological reduction of chromate by Streptomyces griseus. J Hazard Mater 169:539-545

Rawajfih Z, Nsour N (2008) Thermodynamic analysis of sorption isotherms of chromium(VI) anionic species on reed biomass. J Chem Thermodyn 40:846-851 
Richard F, Bourg A (1991) Aqueous geochemistry of chromium: a review. Water Res 25:807-816

Ricordel S, Taha S, Cisse I, Dorange G (2001) Heavy metals removal by adsorption onto peanut husks carbon: characterization, kinetic study and modeling. Sep Purif Technol 24:389-401

Say R, Birlik E, Erdemgil Z, Denizli A, Ersoz A (2008) Removal of mercury species with dithiocarbamate-anchored polymer/ organosmectite composites. J Hazard Mater 150:560-564

Sharma D, Forster CF (1994) A preliminary examination into the adsorption of hexavalent chromium using low-cost adsorbents. Bioresour Technol 47:257-264

Singh KK, Rastogi R, Hasan SH (2005) Removal of Cr(VI) from wastewater using rice bran. J Colloid Interface Sci 290:61-68

Sulaymon AH, Abid BA, Al-Najar JA (2009) Removal of lead, copper, chromium and cobalt onto granular activated carbon in batch and fixed-bed adsorbers. Chem Eng J 155:647-653

Tan WT, Ooi ST, Lee CK (1993) Removal of chromium (VI) from solution by coconut husk and palm pressed fibres. Environ Technol 14:277-282

Unuabonah EI, Olu-Owolabi BI, Adebowale KO, Ofomaja AE (2007) Adsorption of lead and cadmium ions from aqueous solutions by tripolyphosphate-impregnated Kaolinite clay. Coll Surf A Physicochem Eng Asp 292:202-211

Vilar VJP, Botelho CMS, Boaventura RAR (2007) Methylene blue adsorption by algal biomass based materials: biosorbents characterization and process behaviour. J Hazard Mater 147:120-132

Wang L-G, Yan G-B (2011) Adsorptive removal of direct yellow 161 dye from aqueous solution using bamboo charcoals activated with different chemicals. Desalination 274:81-90

Wang S, Boyjoo Y, Choueib A, Zhu H (2005) Removal of dyes from solution using fly ash and red mud. Water Res 39:129-138

Wang XS, Li ZZ, Tao SR (2009) Removal of chromium (VI) from aqueous solution using walnut hull. J Environ Manag 90:721-729

Weber WJ, Morris CJ (1962) Removal of biological resistant pollutants from wastewater by adsorption. Pergamon Press, New York

Weber WJ Jr, Morris JC (1963) Kinetics of adsorption on carbon from solution. J Sanit Eng ASCE 89:31-59

Wong YC, Szeto YS, Cheung WH, McKay G (2003) Equilibrium studies for acid dye adsorption onto chitosan. Langmuir 19:7888-7894

Wu C-H, Chern J-M (2006) Kinetics of photocatalytic decomposition of methylene blue. Ind Eng Chem Res 45:6450-6457

Zhu H-Y, Fu Y-Q, Jiang R, Jiang J-H, Xiao L, Zeng G-M, Zhao S-L, Wang Y (2011) Adsorption removal of congo red onto magnetic cellulose $/ \mathrm{Fe}_{3} \mathrm{O}_{4} /$ activated carbon composite: equilibrium, kinetic and thermodynamic studies. Chem Eng J 173:494-502 